\title{
Author's Ideology In Short Story Of Anthology In Sumi Dan Gambarnya By Ratna Indraswari Ibrahim: Genetic' Structuralism Study
}

\author{
Uman Rejo $^{1 *}$, Nurul Baiti Rohmah ${ }^{2}$ \\ Universitas Timor Jalan Km 9 Kelurahan Sasi, Kefamenanu, Kab. Timor Tengah Utara \\ Provinsi Nusa Tenggara Timur (NTT), Indonesia ${ }^{1}$ \\ Institut Agama Islam Negeri Tulungagung Jalan Mayor Sujadi Timur No. 46 Tulungagung \\ Provinsi Jawa Timur, Indonesia ${ }^{2}$ \\ \{umanrejo@unimor.ac.id ${ }^{1}, \underline{\text { nurulbaitirohamh@iain-tulungagung.ac.id }}{ }^{2}$ \}
}

\begin{abstract}
This research aims to explore and describe the interpretation of the author's ideology about anthology of Sumi dan Gambarnya by Ratna Indraswari Ibrahim. The interpretation was focused on the author's socio-cultural background and the fact of humanity in each short story by Ratna Indraswari Ibrahim in this anthology. The approach used is a genetic structuralism approach. This approach was first introduced by Lucien Goldmann of Perancis. It is amount 5 short stories are used as the objects of study. The research method used is a qualitative descriptive method. The results showed the following. Ratna Indraswari Ibrahim is an accomplished woman who voices a lot about women's issues in the fictional prose such as women who experience discrimination, subordination, have dual roles, receive negative labelling, also those who experience violence. In the fact of humanity, there were various variations of the female narrative that created her voice in ideology. The ideology is the author's creative strategy to fight for gender equality that has remained deeply patriarchal and exclusions for women.
\end{abstract}

Keywords: author's ideology; Ratna Indraswari Ibrahim; genetic structuralism

\section{Introduction}

The author's literary work carries a particular ideological mission. The ideological mission is express and implied. Expressly, the author displays it directly through the proficiency of each character in the story, through dialogues, and so on. Implicitly, the author hides in each scene and conflicts with the story. This means that the implied view is hidden so that the reader can delve deeply into the story's plot and conflicts. Thus, in this case, it is necessary to read intensively and comprehensively to capture the ideological mission that the author wants to convey.

The ideological mission found in literary works has a genetic connection to the sociocultural environment in which the literary work is produced. The socio-cultural condition also influences the homology of the author's thinking in producing literary works. The 
homological relationship is the basis of thinking so that it can produce literary works that correspond to the state of reality in the time in which it was produced. The ideological mission can also appear by the ideals that the author wants to fight for. Hope that has not been conveyed until now can be the original purpose of the literary work it produced. Various phenomena in people's lives can be the starting point for creating ideologically charged literary works. Thus, the various human facts contained in the social reality of discrimination can be a form of expression expressed by the author to reflect it in literary works. As a critical reader, the author's form of expression must be interpreted about the socio-cultural conditions that follow, to find the totality of the meaning in its entirety. Do not interpret literary works by looking from one side only, many other sides can be used as a handle in interpreting them. The vast capital of knowledge can be a foothold towards the interpretation of literary works containing the ideological ideas of each author.

Anthology of short stories titled Sumi dan Gambarnya (2002) was the work of Ratna Indraswari Ibrahim published by PT Gramedia Pustaka Utama for the first time in December 2002 (Ibrahim, 2002). This anthology was composed of 123 pages with a total of 12 different short stories, including "Mimpi Sri", "Serabi Berkuah", "Para Ta'ziah", "Rum Sudah Mati", "Kawin Paksa", "Ngenger", "Sumi dan Gambarnya", "Warna-Warni", "Tudung", "Saya Banowati", "Perempuan di Jalan Lumpang", and "Iklan". Different things were seen in this anthology, as the author does not include the foreword and the source of these short stories that have been published before. The author listed only her brief biography on the last sheet of this anthology.

In short, the purpose of this research was to explore and describe the interpretation of the author's ideology in the short story anthology Sumi dan Gambarnya (2002) by Ratna Indraswari Ibrahim. A genetic structuralism approach was used. This approach was first introduced by Lucien Goldmann of Perancis. According to Wardani (Wardani, 2009), this approach consisted of three things, namely the author's worldview or the ideology he wants to convey, the structure of the text, and the social structure. These three things form the meaning of the totality of literary works solidly. Based on Goldmann (Goldmann, 1994), genetic structuralism has a mission to describe social facts in literary works. The genetic relationship between literary, author, and social works was the basis of his thinking and the relationship affects each other. The relationship had regularity and it was intertwined in the synchronous relationship structure. This relationship covered all areas of humanitarian phenomena. The breadth of the scope of this approach was based on the structuralism belief that all manifestations of social activity began with a structured language. Thus, the nature of regularity in all activities can be simplified into a series of abstract rules such as boundaries and influence over one particular form of social activity known as a human fact.

Wardani (Wardani, 2009) stated that there were three characters behind this approach. First, literary works were seen as a fact of humanity, so they cannot be released from the basic characteristics of human behaviour. The fact that humanity was had a sense of human effort to strike a balance with the surrounding environment through its social, political, and cultural activities. Second, a person's actions were determined by their norms, status, and social groups. Third, this approach recognized that literary works have a wholeness that internally the elements were interconnected and externally related to the socio-cultural conditions of the society that gave birth to them 


\section{Methods}

This research was presented using qualitative descriptive methods. This method is very effectively used to explore and describe the author's ideology in the anthology of short story Sumi dan Gambarnya by Ratna Indraswari Ibrahim. The data source used was distinguished into two, which are primary and secondary data sources. The primary data source was an anthology of short story Sumi dan Gambarnya by Ratna Indraswari Ibrahim published by PT Gramedia Pustaka Utama in 2002. There were five short stories to be covered in this study. Secondary data sources were the data that supported the main focus of this article. The supporting data were in the form of books discussing the works of Ratna Indraswari Ibrahim, other research reports, as well as scientific articles in the form of journal articles or articles published in various media. Because the method used was qualitative descriptive, the data used in the form of words, sentences, and quotations contained in the data source.

The data collection techniques used is library and record techniques. Furthermore, to obtain the validity of the data, the triangulated data was used. In data analysis, the technique used is the content analysis technique. This analysis technique could provide an understanding and explanation of the content analysed. The use of this technique by deciphering the focus of the discussion discussed in this paper objectively, systemically, in detail, and in-depth. This was done with the mission so that the author's ideology contained in the short story anthology can be conveyed optimally. First, described the figure of Ratna Indraswari Ibrahim and the socio-cultural background that encased her. Second, analysed the author's ideology contained in the short story anthology. After using content analysis techniques, the next step was conveyed the results and the language in the form of scientific articles, which are then published in the proceedings of this international seminar.

\section{Results and Discussions}

\section{Ratna Indraswari Ibrahim and Her Socio-Cultural Background}

In her autobiography, Ratna Indraswari Ibrahim was an Indonesian female poet in 1994 who earned the predicate as "Wanita Berprestasi". She was born in Malang, East Java, on 24 April 1949 and died on 28 March 2011 at the age of 61. Her last education was at the Faculty of Administrative Sciences, Universitas Brawijaya (UB), but was not completed. She began her career as a writer seriously in 1978. Some of the resulting literary works, Antologi Kado Istimewa (1992), Pelajaran Mengarang (1993), Lampor (1994), Aminah di Suatu Hari, Menjelang Pati (1994), Laki-laki yang Kawin dengan Peri (1995), Anjing-Anjing Menyerbu Kuburan (1997), Namanya Massa (2000), Lakon Di Kota Senja (2002), Waktu Nayla (2003), Sumi dan Gambarnya (2003), Bukan Pinang di Belah Dua (2003), Lemah Tanjung (2003), Pecinan di Kota Malang (2007), and Lipstik di Tas Doni (2007).

In the literary world, Ratna Indraswari Ibrahim received many awards. Her short stories were consecutively included in Kompas's choice anthology (1993-1996), Surabaya Post's daily preferred short story (1993), and the winner of three short story and story writing competitions held by Femina magazine (1996-1997). In 1996, her short story was selected in the Asean Women's Short Story Anthology. Also, since 1977, she also was an activist as a Chairman of Bhakti Nurani Malang Foundation and a Director I of LSM Ngo Entropic Malang in 1991. By that, she had the opportunity to attend various international seminars including Disable People International in Sydney Australia in 1993, the Women's 
International Congress in Beijing-China (RRC) in 1995, and the MIUSA Leadership Training in Eugene Oregon-USA in 1997.

In accordance with Mansurudin (Mansurudin, 2018), said that the author was unlikely to escape the memory, imagination, events that ended in the realm of reality. Real-life was an experience that becomes capital in supporting the expression of authorship. More and more experience, thought, ideology, and influences his wealth. Ratna Indraswari Ibrahim was an author who is not separated from the power of her time. As an author, she experienced important events in her life. The experience she had did not immediately change the course of her life. There was a process of living her life as an author (Mansurudin, 2018).

Ratna Indraswari Ibrahim was a literary woman with disabilities who does not wanted to be considered as a human being with disabilities. She proofed her-self as disabled, it was when writing, her feet and hands did not worked at all. She used her assistant as her typist, it was her typist who translated all expressions against the results of desire in her literary work (Mansurudin, 2016). Mansurudin (Mansurudin, 2016) confirmed that this became interesting when Ratna Indraswari Ibrahim voiced disability in each of her works as well as the life she faced. Especially life as a woman who was experienced gender injustice. The injustice became so visceral when she was a woman as well as tuna daksa. Instead, she became a surviver under physical, psychic, and state pressure. These factors made it more intense and consistent to fight for commonality, equality, and disability through the literary works (Mansurudin, 2016).

\section{Author's Ideology in Short Story Anthology of Sumi dan Gambarnya}

In the short story "Mimpi Sri", there was a humanitarian ideology conveyed by the author through a female main character named Sri. Yem was unnatural death by suicide, became a conundrum that had to be intimidated by the cause. As a factory payer, Sri had a close relationship with Yem personally. Before she died, Yem had told her about it and complained to her. The money Yem made was spent on her husband at the gambling table. Because Yem's was suicide, Sri often dreamed. Perhaps Sri's dream was a marked of Sri's death. Yem was gave some clue through Sri's dreams. Sri always had a dream with her friends. Through this narrative, it can be said that for every unnatural death, there must be a cause. It was represented expressly or impliedly through the sign presented. It was a form of natural greatness of the causality law that was in this universe. Also, the dream that became the marker as a form of Sri's struggle to further trace the cause of Yem committing suicide, or vice versa, she had been killed. Eventually some people who entered her dream the next day died.

In the short story of "Kawin Paksa", there was a female humanitarian ideology represented through a female main character named Siti. Siti was a village girl who worked as a maid. She was forced to marry a wealthy man in her father's chosen village. Her father was described as a violent parent, while her mother was the one who understands Siti's feelings best. Siti experienced a major dilemma who got married to her father's choice. Various efforts were made so as not to be matched. In village life, the duty of women was as number two while men were number one. In another words, women's duties were not in public spaces as generally the main task as housewives, that is taking care of family, children, and various needs at home. Therefore, parents had an important role to play in finding their child's soul mates if they were not married at an age that should already have a life partner. Accepting circumstances, obeying parents, believing in parents was the ideology of humanity conveyed by the author in this short story. Through the fact of humanity in the short story, that's the ideology of the village women that the author described. 
Siti's gender injustice is the ideal form of Javanese female construction. Based on her gender role, the existence of Javanese women was constructed with 3-M, exactly is "masak" (duty to cook in the kitchen), "macak" (tasked to breast or dress up), and "manak" (tasked with giving birth to children) (Umam, 2015). In the domestic realm, the existence of Javanese women was constructed into three as in "mattress" (bed), "kitchen", and "well". Javanese women were also constructed as Liyan about Javanese men as seen in Javanese female terms as "kanca wingking" (friends in the domestic realm) and women who "swarga nunut neroko katut" (to heaven only "numpang ikut", to hell to be carried away) (Handayani \& Novianto, 2004). All Javanese female construction was seen from Javanese male construction results, nothing showed the intellectual potential of women. Women were discredited and numbered, their freedom of choice was narrowed, so it cannot be realized freely.

In the short story "Sumi dan Gambarnya", there was an ideology of female humanism played by the main character named Sumi. It was told that the main character of Sumi was represented as a simple and independent figure. She was described as a victim of discrimination against the wife committed by her husband. Sumi's wiggle room was restricted by her husband, named Bejo. Marrying Bejo, a widower with three children, made Sumi not felt the happiness of the world and the afterlife. She was forced to marry Bejo at the request of her parents. Nevertheless, Sumi continued to receive it wisely. In this case, Sumi was portrayed as an obedient wife to her husband. If the husband does not allow it, then Sumi would follow him. There was one request of Sumi on Bejo that has not been fulfilled in this case. Sumi wanted to have children with Bejo but he did not wished to have children from Sumi. Bejo was prefered Sumi to keep three children from his previous marriage. Bejo also committed violence by slapping Sumi on the cheek for various things. Forms of discrimination against women committed by husbands should be considered, both expressly and impliedly, both veiled and visible. Patience and high spirit were displayed through the character of Sumi so that it could be a source of example for women today. The public rights that women should enjoy were limited. In this case, Sumi's position as Bejo's wife was very marginalized. By limiting Sumi's wiggle room in public spaces. This was a misrepresentation of women represented through the character of Sumi.

Subordination to women means women have no opportunity to make decisions, even decisions that concern themselves. Women are required to submit to decisions taken by men (Simatauw, Simanjuntak, \& Kuswardono, 2001). Syafe'i (Syafe'i, 2015) explained that the subordination of "lumrah" women developed in a patriarchal culture, where it places women's positions on the less profitable in terms of both social, economic, and political. The weak economic position would affect the communication and negotiation process in decisionmaking forums, both in the household and in the wider community.

In another story of "Tudung", there was a humanitarian ideology of career women depicted by the author through a female character named Rosalina. Rosalina was described as a woman who held the position of secretary of the company's director. Rosalina has a husband named Erwin who was busy working on her doctoral dissertation. In the story, there was a dual role experienced by Rosalina, as a wife and housewife, as well as a career woman who was got high position. Both of them lived in a balanced manner that she was very responsible for this. He doesn't neglect her daily duties. Erwin also understands the dual role that Rosalina was performed. Erwin always reminds us, in living it, communication with the family must be intertwined so that harmony would be obtained. Also, knowing her good self-position in the family, in the office, and society was done equally as a consequence of being a woman who has a dual role like Rosalina's. The author was very good at expressing in detail every action 
Rosalina did. Self-reliance, responsibility, was the key to the author's ideology through this short story.

Another short story of "Saya Banowati", there was a career female humanism ideology represented by the author through a female main character named Banowati. She was a career woman who got a husband. The husband of this main character named Suyudono, who had a brilliant career, often out of town because of his duties, rarely at home and also rarely gathered in the family, as found in the humanitarian facts of this short story. In Banowati's loneliness, a character named Arjuna appears. This character was portrayed as a man who was attentive to Banowati, familiar, kind, more understanding of the feelings of women, nevertheless, the closeness between Banowati and Arjuna still had limits. The female main character was good at controlling herself. Although the closeness between the two was like a dating person, the two still had strong self-control. Some of Banowati's friends had warned to stay away from Arjuna. Some was concerned about her relationship with Arjuna have been accepted. That was the greatness of this main character that the author described. Family, children, and husbands became the main priorities despite having a brilliant career. Friendship and friendship with anyone was not the main issue, but the commitment that had been maintained in the family was the main foundation. Also, beliefs, loyalties, and beliefs must also be maintained.

\section{Conclusions}

Based on the descriptions above, it can be concluded that the issues about women's lives voiced by Ratna Indraswari Ibrahim through her literary work showed that much to be concerned about treating women like women. The ideologies she claimed through her literary work proved that there were some more unfair treatments experienced by women. Various forms of subordination, dual roles, stereotypes against women, negative labelling of women, discrimination, violence against women were either physically, non-physical, or symbolically represented in this short story anthology. As a critical reader, these varied forms of injustice were not something that was discrete, but rather should get serious attention. The attention became the form of a bridge to leave these forms of justice.

Ratna Indraswari Ibrahim was a female activist who fights for women's spirit to be more advanced than ever. She showed the world that women were capable of doing it. In genetic relationships, there was a large ideology of the author reflected in the object of this study. Through the reading on 12 short stories, only five short stories can be presented given the limitations of the space presented in the writing systematics in this article. Women remained women, therefore ideal women did not violate the nature that they had. Women wanted to perform in public spaces, they did not wanted to show their superpowers and defeat men, but rather between women and men having equal rights in different fields as men do today.

\section{References}

[1] Goldmann, L. (1994). The Wager of Lucien Goldmann: Tragedy, Dialectics and A Hidden God. Trans. Mitchel Choen. United Kingdom: Princeton University Press.

[2] Handayani, C. S., \& Novianto, A. (2004). Kuasa Wanita Jawa. Yogyakarta: LKIS.

[3] Ibrahim, R. I. (2002). Sumi dan Gambarnya. Jakarta: Gramedia Pustaka Utama.

[4] Mansurudin, S. (2016). Citra Difebilitas dalam Karya Ratna Indraswari Ibrahim. 
Parafrase, 16 (1).

[5] Mansurudin, S. (2018). Epiphany of Ratna Indraswari Ibhahim as Author. Bahasa Dan Seni: Jurnal Bahasa, Sastra, Seni, Dan Pengajarannya, 46 (1), 44-56.

[6] Simatauw, M., Simanjuntak, L., \& Kuswardono, P. T. (2001). Gender dan Pengelolaan Sumber Daya Alam: Sebuah Panduan Analisis. Wandita G, Pengantar. Kupang: Yayasan PIKUL (Penguatan Institusi Dan Kapasitas Lokal).

[7] Syafe'i, I. (2015). Subordinasi Perempuan dan Implikasinya Terhadap Rumah Tangga. Analisis: Jurnal Studi Keislaman, 15(1), 143-166.

[8] Umam, M. H. (2015). Buku Saku: Gender, Islam dan Budaya. Surabaya: Pusat Studi Gender Dan Anak (PSGA) UIN Sunan Ampel Surabaya.

[9] Wardani, N. E. (2009). Makna Totalitas dalam Karya Sastra. Solo: UNS. 